\title{
Peran Penyuluh Dan Strategi Pemasaran Dalam Meningkatkan Volume Penjualan Kelompok Nelayan Desa Madong Tanjungpinang
}

\author{
Lia Suprihartini, Roni Kurniawan \\ Fakultas Ekonomi Universitas Maritim Raja Ali Haji, Tanjungpinang, Kepulauan Riau, Indonesia
}

\begin{abstract}
ABSTRAK : Penelitian ini membahas tentang peran penyuluh dan bagaimana strategi pemasaran yang diduga mempengaruhi volume penjualan kelompok nelayan desa Madong Tanjungpinang. Dalam penelitian ini variable peran penyuluh dilihat dari indikator kinerja dan kompetensi; strategi pemasaran dilihat dari indikator market segmentasi, market positioning, market entry strategi, marketing mix; serta volume penjualan dari indikator Laba dan Penjualan. Penelitian ini menggunakan aplikasi program SPSS.V.24, meunjukkan bahwa secara parsial Strategi Penjualan berpengaruh secara positif dan signifikan terhadap Volume Penjualan dan Peran Penyuluh berpengaruh secara secara positif dan signifikan terhadap Volume Penjualan. Secara simultan Peran Penyuluh dan Strategi Penjualan berpengaruh positif dan signifikan terhadap Volume Penjualan.
\end{abstract}

Kata Kunci : Peran Penyuluh, Strategi Pemasaran, Volume Penjualan

\begin{abstract}
This study discusses the role of extension agents and how marketing strategies are thought to affect the sales volume of the fishermen group in Tanjung Pinang village. In this study the role of instructor variables is seen from performance and competency indicators; marketing strategy seen from indicators of market segmentation, market positioning, market entry strategy, marketing mix; and sales volume of profit and sales indicators. This study uses the SPSS.V.24 program application, showing that partially the Sales Strategy has a positive and significant effect on Sales Volume and the Extension Role has a positive and significant effect on Sales Volume. Simultaneously the Extension Role and Sales Strategy have a positive and significant effect on Sales Volume
\end{abstract}

Keywords: Extension Role, Marketing Strategy, Sales Volume

Email Address : liasuprihartini@umrah.ac.id 


\section{Pendahuluan}

Sektor perikanan di Indonesia sangat bervariasi mulai dari bentuk penangkapan (capture) maupun budidaya (culture) semuanya dapat diterapkan Tercapainya program pemerinatah dalam bidang budidaya perikanan. Tentu tidak terlepas dari pelatihan, pengembangan dan pendampingan yang diberikan oleh tenaga penyuluh perikanan agar dicapai hasil budidaya perikanan yang berkualitas sehingga dapat memberikan pengaruh yang signifikan salah satunya terhadap kesejahteraan masyarakat kelompok nelayan itu sendiri. Penyuluh perikanan merupakan agen perubahan yang berada di tengah-tengah masyarakat perikanan (nelayan, pembudidaya dan pengolah hasil perikanan) dengan adanya penyuluh diharapkan bisa merubah pola pikir (mindset) dalam menghadapi masalah, isu dan informasi teknologi terbarukan.

Persentase penjualan ikan hasil Kelompok Nelayan Desa Madong Tanjungpinang yang notabene sudah 3-4 Tahun terbentuk, saat ini bisa dikatakan belum maksimal. Terlihat dari data produksi ikan pada tahun 2016-2018 jumlah tidak stabil dan cenderung mengalami penurunan. Dari total data produksi 4 kelompok, terlihat tidak semua kelompok dapat produktif menghasilkan hasil produksi budidaya yg baik. Dapat terlihat dari Tabel Produksi dibawah ini :

\begin{tabular}{|l|c|c|c|}
\hline \multicolumn{1}{|c|}{ Nama Kelompok } & Jumlah Produski th 2016 & Jumlah Produksi & Jumlah Produksi 2018 \\
\hline Bawal Bintang & $7280 \mathrm{~kg}$ & $5892 \mathrm{~kg}$ & Sampai Juni 938 kg \\
\hline Rezeky Pesisir & $6278 \mathrm{~kg}$ & $5521 \mathrm{~kg}$ & $667 \mathrm{~kg}$ \\
\hline Maju Mandiri & $5997 \mathrm{~kg}$ & $6534 \mathrm{~kg}$ & $743 \mathrm{~kg}$ \\
\hline Berkelana & $5886 \mathrm{~kg}$ & $5379 \mathrm{~kg}$ & $632 \mathrm{~kg}$ \\
\hline
\end{tabular}

Terlihat dari table diatas bahwa jumlah produksi budidaya ikan pada kelompok Budidaya di desa Madong cenderung tidak stabil dan mengalami penurunan. Hal tersebut dikarenakan banyak persentase kelulusan hidup ikan yang rendah. Dari persentase 100\% bibit ikan yang ditebar, perkiraan kelulusan hidup hanya $60 \%$ sampai $70 \%$.

Dari segi penjualan hasil produk budidaya, distribusi penjualan hanya dilakukan melalui pemasaran langsung ke pemasok (biasanya hotel), melalui cukong , serta pemasaran langsung ke masyarakat sekitar sebagai pengguna akhir produk tersebut. Tarif harga yang diberikan terkadang cenderung lebih rendah atau dengan kata lain harga yang diberikn relative murah. Sehingga dengan kondisi tersebut tentu dirasa belum dapat memberikan perubahan dampak terhadap kesejahteraan hidup para anggota kelompok tani di desa Madong tersebut dikarenakan volume penjualan yang rendah.

Pentingnya peran penyuluh memiliki kompetensi yang baik dalam memberikan pelatihan, penyuluhan serta pendampingan dirasa sangat besar dampaknya untuk memberikan perubahan dalam pola menghasilkan produk ikan yang berkualitas. Selain itu juga sangat diperlukan peran serta penyuluh perikanan dalam memberikan pendampingan dalam pendistribusian produk hasil budidaya agar dapat terserap dengan baik dipasar. Dengan strategi pemasaran yang berbeda yang nantinya dapat memberikan kontribusi terhadap perubahan taraf hidup para anggota kelompok nelayan Desa Madong tersebut.

\section{Perumusan Masalah}

Permasalahan dalam penelitian ini adalah "apakah peran penyuluh, strategi pemasaran berpengaruh terhadap peningkatkan volume 
penjualan kelompok nelayan desa madong tanjungpinang baik secara parsial maupun secara simultan"

\section{Tujuan Penelitian}

Tujuan Penelitian ini adalah untuk mengetahui pengaruh Variabel Peran Penyuluh dan Strategi Pemasaran terhadap Volume Penjulam baik secara Parsial dan secara Simultan

\section{Landasan Teori}

\section{Peran Penyuluh}

Tenaga Penyuluh memiliki peran penting dalam merubah perilaku suatu kelompok masyarakat. Tujuan penyuluhan pertanian adalah berubahnya perilaku petani yang mencakup perubahan dalam hal pengetahuan atau hal yang diketahui, perubahan dalam keterampilan atau kebiasaan dalam melakukan sesuatu dan perubahan dalam sikap dan mental kearah yang lebih baik dengan tujuan akhir penyuluhan adalah kesejahteraan hidup yang lebih baik (Walhidayah, 2014).

Sejalan dengan implementasi amanah UU No. 16/2006 tentang SP3K, maka guna memanfaatkan potensi sumberdaya kelautan dan perikanan Indonesia yang sangat besar bagikemajuan, kemakmuran, dan kesejahteraan bangsa dan negara secara berkelanjutan diperlukanadanya SDM yang handal dan profesional. Penyuluh Perikanan memegang peranan pentingdalam upaya pencapaian peningkatan kualitas Sumber Daya Manusia pelaku utama/ pelakuusaha sebagai mediator, motifator dan fasilitator. Dalam mewujudkan peran tersebut penyuluh harus memiliki kapasitas dan kompetensi yang tinggi dalam melaksanakan fungsi pembinaandan pendampingan dalam menjalankan tugasnya.

$$
\text { Menurut Wibowo (2007:110) }
$$

menyebutkan bahwa kompetensi adalah suatu kemampuan untuk melaksanakan atau melakukan suatu pekerjaan atau tugas yang dilandasi atas keterampilan dan pengetahuan serta didukung oleh sikap kerja yang dituntut oleh pekerjaan tersebut. Dengan demikian, kompetensi menunjukkan keterampilan atau pengetahuan yang dicirikan oleh profesionalisme dalam suatu bidang tertentu sebagai sesuatu yang terpenting, sebagai unggulan bidang tertentu, dengan indikatornya adalah a) Pengetahuan (Knowledge) Pengetahuan yang berkaitan dengan pekerjaan ,b) Keterampilan (Skill) , c) Sikap (Attitude). Adapun Kompetensi menurut Veithzal (2003:298), kompetensi yaitukecakapan, keterampilan, kemampuan. Kata dasarnya sendiri, yaitu kompeten yang berarti cakap, mampu, terampil. Kompetensi mengacu kepada atribut/ karakteristik seseorang yang membuatnya berhasil dalam pekerjaannya.

Peran Penyuluh Lapangan dapat kita lihat juga dari bagaimana kinerja penyuluh tersebut dilapangan. Menurut Prabu Mangunegara (2010: 67) bahwa kinerja karyawan adalah hasil kerja secar kualitas dan kuantitas yang dicapai oleh seseorang karyawan dalam melaksanakan tugasnya sesuai dengan tanggung jawab yang di berikan kepadanya. Kinerja diukur dengan instrumen yang dikembangkan dalam studi yang tergabung dalam ukuran kinerja secara umum kemudian diterjemahkan kedalam penilaian perilaku secara mendasar, meliputi:

a) Kuantitas kerja,

b) Kualitas kerja,

c) Pengetahuan tentang pekerjaan,

d) Perencanaan kegiatan.

\section{Strategi Pemasaran}

Strategi pemasaran pada dasarnya adalah rencana yang menyeluruh, terpadu dan menyatu dibidang pemasaran, yang memberikan panduan tentang kegiatan yang akan dijajalankan untuk dapat tercapainya tujuan pemasaran.

Strategi Pemasaran Menurut Philip Kotler ( 2004, 81 ): "Strategi Pemasaran adalah pola pikir pemasaran yang akan digunakan untuk mencapai tujuan pemasarannya. Strategi pemasaran berisi strategi spesifik untuk pasar 
sasaran, penetapan posisi, bauran pemasaran dan besarnya pengeluaran pemasaran."

Seiring dengan itu, menurut tjiptono ( 2002, 6 ) : "Strategi pemasaran adalah alat fundamental yang direncanakan untuk mencapai perusahaan dengan mengembangkan keunggulan bersaing yang berkesinambungan melalui pasar yang dimasuki dan program pemasaran yang digunakan untuk melayani pasar sasaran tersebut." Strategi pemasaran didasarkan atas 5 (lima) konsep strategi sebagai berikut : 1) Market Segmentation (Segmentasi Pasar), 2) Market Positioning, 3) Market Positioning, 4) Marketing Mix Strategy, 5) Timing Strategy.

\section{Volume Penjualan}

Penjualan selalu dihubungkan dengan istilah volume penjualan. Berhasil tidaknya suatu perusahaan dapat dilihat dari kondisi volume penjualan secara keseluruhan. Volume Penjualan menurut John Downes dan Jordan Elliot Goodman yang dikutip oleh Susanto Budidharmo (2000:646), yaitu : "Volume

\section{Kerangka Konseptual}

penjualan adalah total penjualan yang didapat dari komoditas yang diperdagangkan dalam suatu masa tertentu.

Sedangkan menurut Swastha (2003:141), menyatakan bahwa: "Volume penjualan merupakan penjualan bersih dari laporan laba perusahaan. Penjualan bersih diperoleh melalui hasil penjualan seluruh produk (produk lini) selama jangka tertentu, dan hasil penjualan yang diperoleh dari market share (pangsa pasar) yang merupakan penjualan potensial, yang dapat terdiri dari kelompok teritorial dan kelompok pembeli saham jangka waktu tertentu"

Berdasarkan definisi diatas dapat disimpulkan bahwa volume penjualan merupakan hasil dari kegiatan penjualan yang dilakukan pihak produsen dalam hal ini adalah perusahaan ketangan konsumen dalam usahanya mencapai sasaran yaitu memaksimalkan laba untuk periode yang ditentukan.

peningkatkan volume penjualan kelompok nelayan desa madong tanjungpinang

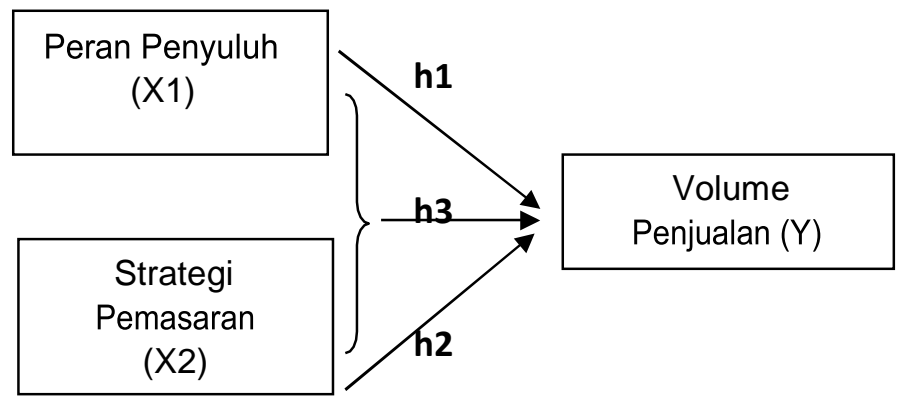

Dari kerangka konseptual diatas, maka hipotesis dari peneltian ini adalah :

H1 : Peran penyuluh berpengaruh terhadap peningkatkan volume penjualan kelompok nelayan desa madong tanjungpinang

$\mathrm{H} 2$ : Strategi Pemasaran berpengaruh terhadap peningkatkan volume penjualan kelompok nelayan desa madong tanjungpinang

H3 : Peran penyuluh dan Strategi Pemasaran berpengaruh terhadan

\section{Metodologi Penelitian}

Jenis penelitian pada penelitian ini adalah penelitian kuantitatif. Menurut Sugiyono (2015 :35) kuantitatif adalah metode penelitian yang berlandasan pada filsasaf positivisme yang digunakan untuk meneliti populasi atau sampel tertentu, pengumpulan data dengan menggunakan instrumen penelitian, analisis data bersifat kuantitatif/statistik, dengan tujuan untuk menguji hipotesis yang telah ditetapkan. Berdasarkan pendapat tersebut dapat dipahami 
pengaruh yang ingin diketahui dalam penelitian ini yaitu Peran Penyuluh (X1), Strategi Pemasaran (X2),sertaVolume Penjualan (Y) .

\section{Pengambilan Sampel}

Pengambilan sampel yang digunakan dalam penelitian ini adalah teknik nonprobability sampling dengan menggunakan teknik sampel jenuh. Menurut Sugiyono (2015 : 156) mengungkapkan bahwa sampel jenuh adalah teknik penentuan sampel bila semua anggota populasi dijadikan sampel. Hal ini dilakukan bila jumlah populasi relatif kecil, dalam penelitian ini sampel yang diambil seluruh anggota dalam kelompok nelayan Desa Madong yaitu sebanyak 40 orang.

\section{Teknik Analisa Data}

\section{Analisa Regresi Linier Berganda}

Dalam penggunaan persamaan regresi berganda adalah terpenuhinya uji asumsi klasik. Adapun pengujiannya sebagai berikut Uji Normalitas, bertujuan untuk menguji apakah dalam model regresi variabel pengganggu atau residul memilik distribusi normal. Seperti diketahui bahwa uji $\mathrm{T}$ dan $\mathrm{F}$ mengasumsikan bahwa nilai residual mengikuti distribusi normal; Uji Multikolinearitas, untuk menguji apakah model regresi ditemukan adanya korelasi antar variabel bebas (independen). Untuk mendeteksi ada atau tidaknya multikolinearitas di dalam regresi; Uji Heteroskedastisitas, bertujuan untuk menguji apakah dalam model regresi terjadi ketidaksamaan variabel dari residual satu pengamatan ke pengamatan yang lain; Uji Autokorelasi, digunakan untuk menguji apakah dalam suatu model regresi linier terdapat korelasi antara kesalahan pengganggu pada periode $t$ dengan kesalahan pada $t$ dari nilai uji Durbin - Watson

\section{Analisis dan Pembahasan Profil Responden}

Dalam penelitian ini dari sampel sebanyak 40 orang, kesemuanya adalah laki-laki yang menunjukkan bahwa nelayan pada dasarnya bergender laki-laki yang berusia antara 31 sampai 50 tahun. Memiliki rata-rata pendidikan pada jenjang Sekolah menengah pertama.

Analisa Regresi Linier berganda

\section{Hasil Analisis Koefisien Determinasi}

\begin{tabular}{ll|l|l|r} 
& & \multicolumn{2}{c}{ Model Summary } \\
Model & $\mathrm{R}$ & R Square & $\begin{array}{c}\text { Adjusted R } \\
\text { Square }\end{array}$ & $\begin{array}{l}\text { Std. Error of } \\
\text { the Estimate }\end{array}$ \\
\hline 1 & $.762^{\mathrm{a}}$ & .580 & .557 & 1.586 \\
\hline $\begin{array}{l}\text { a. Predictors: (Constant), Peran_Penyuluh, Strategi } \\
\text { b. Dependent Variable: Volume_Penjualan }\end{array}$
\end{tabular}

Dari Tabel diatas, dapat dilihat bahwa angka $\mathrm{R}$ disebut koefisien korelasi antara variabel Peran Penyuluh dan Strategi Penjualan dengan Volume Penjualan. adalah 0,762. Ini artinya hubungan antara Peran Penyuluh dan Strategi Penjualan dengan Volume Penjualan adalah kuat (signifikan) sebesar 76,2\%. Adjusted R2 dalam penelitian ini mendapat nilai 0,580 , hal ini menujukkan bahwa sebesar $58 \%$ voleme penjualan dipengaruhi oleh Peran Penyuluh dan Strategi Penjualan. Sedangkan sisanya sebesar $42 \%$ diduga dipengaruhi atau dijelaskan oleh faktorfaktor lain yang tidak termasuk dalam 
penelitian ini. Hal ini sesuai dengan yang dikatakan Ghozali (2006:170).dimana Koefisien determinasi (R2) pada intinya mengukur seberapa jauh kemampuan model dalam menerangkan variasi-variabel dependen yang dalam penelitian ini mendapatkan nilai R2sebesar $58 \%$.

\section{Uji F}

\begin{tabular}{|c|c|c|c|c|c|c|}
\hline \multicolumn{7}{|c|}{ ANOVAa } \\
\hline Model & & Sum of Squares & $\mathrm{df}$ & Mean Square & $\mathrm{F}$ & Sig. \\
\hline \multirow[t]{3}{*}{1} & Regression & 128.552 & 2 & 64.276 & 25.559 & $.000^{\mathrm{b}}$ \\
\hline & Residual & 93.048 & 37 & 2.515 & & \\
\hline & Total & 221.600 & 39 & & & \\
\hline
\end{tabular}

a. Dependent Variable: Volume_Penjualan

b. Predictors: (Constant), Peran_Penyuluh, Strategi

Berdasarkan Tabel diatas, dapat disimpulkan bahwa nilai signifikansi 0,000 dan nilai $\mathrm{F}$ hitung25,559. Ini berarti nilai sig lebih kecil dari $0,05(0,000<0,05)$. Dan berdasarkan perbandingan $\mathrm{F}$ hitung dengan $\mathrm{F}$ tabel ( $\mathrm{F}$ tabel $\alpha=0,05, \mathrm{df}=40$ ) didapat $\mathrm{F}$ hitung 25,559 lebih besar dari F tabel yaitu 3,23 (25,559> 3,23). Maka dalam hal ini Ha diterima dan H0 ditolak yang menunjukkan bahwa Peran Penyuluh dan Strategi Penjualan secara simultan berpengaruh positif dan signifikan terhadap Volume Penjualan

\section{Uji t}

\begin{tabular}{|c|c|c|c|c|c|c|}
\hline \multirow[b]{3}{*}{ Model } & \multicolumn{6}{|c|}{ Coefficients $^{a}$} \\
\hline & & \multicolumn{2}{|c|}{ Unstandardized Coefficients } & \multirow{2}{*}{$\begin{array}{c}\text { Standardized } \\
\text { Coefficients } \\
\text { Beta } \\
\end{array}$} & \multirow[b]{2}{*}{$\mathrm{t}$} & \multirow[b]{2}{*}{ Sig. } \\
\hline & & $\mathrm{B}$ & Std. Error & & & \\
\hline \multirow[t]{3}{*}{1} & (Constant) & 3.973 & 5.022 & & .791 & .434 \\
\hline & Strategi & .152 & .089 & .182 & 1.700 & .097 \\
\hline & Peran_Penyuluh & .618 & .092 & .722 & 6.744 & .000 \\
\hline
\end{tabular}

a. Dependent Variable: Volume_Penjualan

a) Variabel Strategi Penjualan nilai sig

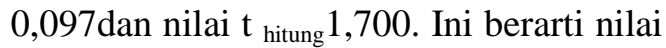
sig lebih besardari taraf signifikansi 0,05 $(0,097<0,05)$. Dan berdasarkan perbandingan $\mathrm{t}$ hitung dengan $\mathrm{t}$ tabel $(\mathrm{t}$ tabel $\alpha=0,05, \mathrm{df}=40$ ) didapat $\mathrm{t}$ hitung 1,700 lebih besar dari $\mathrm{t}$ tabel $1,683(1,700>1,683)$. Maka dalam hal ini $\mathrm{H}_{\mathrm{a}}$ diterima dan $\mathrm{H}_{0}$ ditolak sehingga Strategi Penjualanberpengaruh secara positif dan signifikan terhadap Volume Penjualan b) Variabel Peran Penyuluh nilai sig 0,000 dan nilai $t_{\text {hitung }} 6,744$. Ini berarti nilai sig lebih kecil dari taraf signifikansi 0,05 $(0,000<0,05)$. Dan berdasarkan perbandingan $\mathrm{t}$ hitung dengan $\mathrm{t}$ tabel $(\mathrm{t}$ tabel $\alpha=0,05, \mathrm{df}=40$ ) didapat $\mathrm{t}$ hitung 6,744 lebih besar dari $t$ tabel 1,683 (6,744> 1,683). Maka dalam hal ini $\mathrm{H}_{\mathrm{a}}$ diterima dan $\mathrm{H}_{0}$ ditolak sehingga Peran Penyuluh berpengaruh secara secara positif dan signifikan terhadap Volume Penjualan 
FE Universitas Maritim Raja Ali Haji

\section{Uji Asumsi Klasik}

\section{Coefficients $^{\mathrm{a}}$}

\begin{tabular}{ll|r|r} 
Model & & Tolerance & \multicolumn{1}{l}{ VIF } \\
\hline 1 & (Constant) & & \\
\cline { 2 - 4 } & Strategi & .990 & 1.010 \\
\cline { 2 - 4 } & Peran_Penyuluh & .990 & 1.010 \\
\hline
\end{tabular}

a. Dependent Variable: Volume_Penjualan

Berdasarkan Tabel diatas, dapat dilihat hasil perhitungan menunjukkan nilai toleransi variabel independen memiliki nilai tolerance $0,990>0,10$ dan hasil perhitungan nilai VIF juga menunjukkan variabel independen memiliki nilai VIF $1,010<10$. Dengan demikian dapat disimpulkan bahwa tidak terjadi multikolinearitas antar variable bebasnya (independen) dalam model regresi

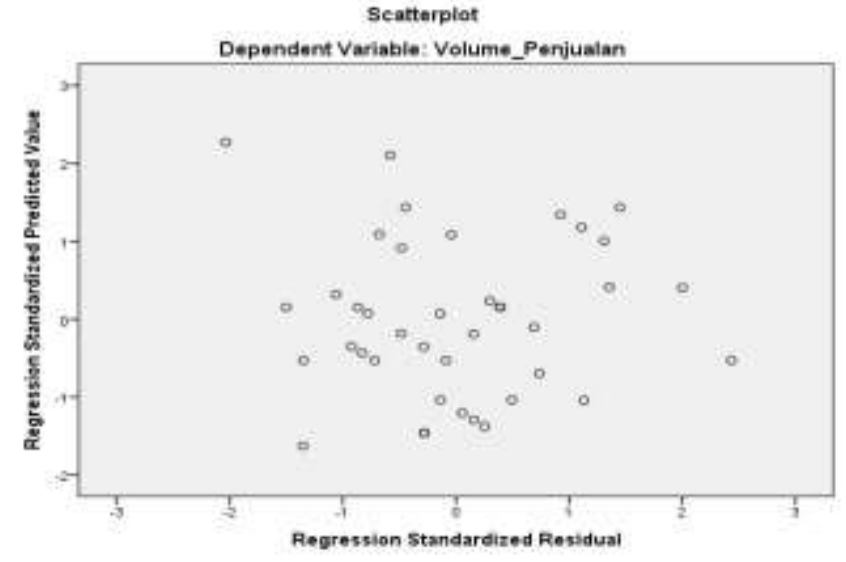

Dari Gambar scatterplot diatas, terlihat bahwa titik-titik menyebar secara acak serta tersebar baik diatas maupun dibawah angka 0 pada sumbu Y. Hal ini dapat disimpulkan bahwa tidak terjadi heteroskedastisitas pada model regresi, sehingga model regresi layak dipakai untuk memprediksi volume penjualan berdasarkan masukan variabel independen peran penyuluh dan strategi penjualan.

\section{Hasil Uji Kolmogorov-Smirnov}

One-Sample Kolmogorov-Smirnov Test

\begin{tabular}{llr} 
& $\begin{array}{r}\text { Unstandardi } \\
\text { zed Residual }\end{array}$ \\
\hline $\mathrm{N}$ & & 40 \\
\hline Normal Parameters $^{\mathrm{a}, \mathrm{b}}$ & Mean & .0000000 \\
\hline
\end{tabular}




\begin{tabular}{llr}
\hline & $\begin{array}{l}\text { Std. } \\
\text { Deviation }\end{array}$ & 1.54461739 \\
\hline Most Extreme & Absolute & .068 \\
\cline { 2 - 3 } Differences & Positive & .068 \\
\cline { 2 - 3 } & Negative & -.048 \\
\hline Test Statistic & & .068 \\
\hline Asymp. Sig. (2-tailed) & & $.200^{\text {c,d }}$ \\
\hline
\end{tabular}

a. Test distribution is Normal.

b. Calculated from data.

c. Lilliefors Significance Correction.

d. This is a lower bound of the true significance.

Berdasarkan Tabel diatas, dengan melihat nilai Kolmogorov-Smirnov dan nilai Asymp. Sig. (2-tailed) adalah 0,200>0,05.

Hal ini berarti data residual terdistribusi normal.

\section{Analisis Pengaruh Variabel Peran Penyuluh dan Strategy Pemasaran Terhadap Volume Penjualan}

Pada Variabel Peran Penyuluh memiliki pengaruh yang lebih besar terhadap volume penjualan. Hal ini terkait dengan dimensi kinerja dan kompetensi yang dimiliki oleh penyuluh lapangan agar hasil produk budidaya yang dihasilkan dapat mencapai hasil yang maksimal. Antara lain mencakup tahap kelulusan hidup yang lebih tinggi, dari segi kesehatan dan pakan produk budidaya, bagaimana agar hasil produk budiaya yang dihasilkan lebih berkualitas. Sehingga nilai jual dari produk budidaya ikan kelompok nelayan desa Madong dapat lebih baik.

Pada variable strategi penjualan secara signifikan juga sangat mempengaruhi volume penjualan. Sejauh ini distribusi penjualan hanya melalui cukong yang memberikan harga yang relative lebih murah serta pemasaran secara local yang dilakukan disekitar kota Tanjungpinang, melalui pemasaran ke restoran-restoran local, dengan harga yang juga relative lebih murah. Tingkat kelulusan hidup ikan yang rendah mengakibatkan jumlah produksi yang rendah sekitar $60 \%-70 \%$ dari total bibit awal yang ditanam sebesar $100 \%$, mengakibatkan kelompok nelayan desa Madong tidak mampu mengakomodir kebutuhan pasar yang lebih besar pada waktu permintaan terhadap hasi budidaya tersebut meningkat, seperti kebutuhan yang lebih banyak pada hari-hari besar Agama missal hari Raya Imlek, tahun baru dan lain sebagainya. Ketika hasil produk budidaya meningkat dengan kualitas produk budidaya yang baik, tentu menjadi suatu keunggulan agar produk budidaya dapat lebih diperluas lagi cakupan pasar penjualan sehingga mampu mengakomodir kebutuhan pasar bahkan sampai pasar luar negeri. Tentu dengan hasil penjualan yang baik akan dapat meningkatkan kesejahteraan dari para anggota kelompok nelayan Desa Madong tersebut.

\section{Kesimpulan dan Saran}

\section{Kesimpulan}

Berdasarkan hasil yang didapat melalui analisa data dalam penelitian mengenai pengaruh Peran Penyuluh dan Strategi Pemasaran terhadap Volume Penjualan pada Kelompok Nelayan desa Madong Tanjungpinang, terdapat beberapa kesimpulan yang dapat diambil yaitu :

1. Secara Parsial Peran Penyuluh berpengaruh secara positif dan signifikan terhadap Volume Penjualan

2. Secara Parsial Strategi Penjualan 
berpengaruh secara positif dan signifikan terhadap Volume Penjualan

3. Secara Simultan Peran Penyuluh dan Strategi Penjualan berpengaruh positif dan signifikan terhadap Volume Penjualan

\section{Saran}

1. Seluruh variable bebas dalam penelitian ini memberikan pengaruh yang signifikan terhadap peningkatan volume penjualan. Oleh karena itu diharapkan pemerintah melalui Dinas Kelautan dan Perikanan, dapat lebih meningkatkan peran serta penyuluh lapangan, dalam meningkatkan kualitas maupun kuantitas hasil produk budidaya sehingga mampu memenuhi kebutuhan pasokan produk budidaya baik secara local maupun luar negeri

2. Selain dalam hal pengelolaan produk budidaya, diharapkan peran penyuluh lapangan juga dalam bentuk pendampingan terhadap distribusi hasil produk budidaya tersebut. Misalnya dengan cara menggali data exportir dan melakukan Pola kemitraan dalam pendistribusian produk budidaya tersebut.

3. Diharapkan peningkatan Peran serta para stakeholder baik swasta maupun BUMN serta pihak lain nya dalam peningkatan produktivits kelompok nelayan Desa Madong, misalkan melalui kegiatan CSR, baik dalam hal pemberian bantuan bibit, peralatan, dll serta pendampingan dalam kegiatan budidaya perikanan tersebut.

\section{Daftar Pustaka}

Anjang Sari, I. dkk. (2015). Strategi Pemasaran Dalam Meningkatkan Volume Penjualan Pada PT. HATNI (Hasil Alam Tani Nelayan Indonesia Di Desa Tlogosadang Kecamatan Paciran Kabupaten Lamongan Jawa Timur. Jurnal ECSOFiM Vol. 3 No. 1,2015
Alma, Buchari, 2007, Manajemen Pemasaran dan Pemasaran Jasa, Edisi Revisi, Alfabeta: Bandung

Anwar Prabu Mangkunegara, (2010), Manajemen Sumber Daya Manusia Perusahaan, Remaja Rosdakarya, Bandung

Assauri, Sofjan.(2004). Manajemen Pemasaran. Jakarta: Rajawali Press.

Armstrong, Gary dan Kotler, Philip, (2008), Prinsip-prinsip pemasaran, Edisi 12, Erlangga: Jakarta.ion: New Jersey

Armstrong, Gary dan Kotler, Philip, Marketing; An Intriduction, Edisi 8, Pearson Educat

Djaman Satori. (2007). Profesi Keguruan. Jakarta: Universitas Terbuka

Effendi, I. (2005). Dasar-Dasar Penyuluhan Pertanian. Fakultas Pertanian. Universitas Lampung. Bandar Lampung 2005

Faqih Achmad, (2014). Peranan Penyuluh Pertanian Lapangan (PPL) dalam Kegiatan Pemberdayaan Kelompok Terhadap Kinerja Kelompok Tani. Jurnal Agrijati Vol 26 No 1, Agustus 2014

Kallapur, Sanjay dan Trombley, Mark A. (2001). The Invesment Opportunity Set : Determinant, Consequences and Measurement. Manajerial Finance 315

Kotler dan Armstrong. (2004). Prinsipprinsip Pemasaran. Alih Bahasa oleh Wisnu Chandra Kristiaji. Jilid 2. Edisi Kedelapan. Jakarta : Erlangga.

Kotler, Phillip (2008) Manajemen Pemasaran Edisi 12. Jakarta. Indeks 
FE Universitas Maritim Raja Ali Haji

Lakip Kepulauan Riau Tahun (2015)

Safrida, T. dkk. (2015). Peran Penyuluh Perikanan dalam Pengembangan Sektor Perikanan di Kabupaten Aceh Utara. Peneliti Sosial Ekonomi Pertanian, Banda Aceh

Swastha, Basu (2008). Manajemen Pemasaran Modern. Yogyakarta: Liberty

Tjiptoni, Fandy, (2008), Strategi Pemasaran, Edisi 3, ANDI: Yogyakarta

Rivai Veithzal. (2003). Manajemen Sumber Daya Manusia Untuk Perusahaan. Jakarta: Rajawali Grafindo Persada

Walhidayah. (2014). Landasan Teori Penyuluhan Pertanian https://pemudapelita.wordpress.com/ 2014/06/16/93/contoh diakses tanggal 13 Maret 2018

Wibowo, (2007). Dalam Bukunya berjudul Sistem Manajemen Kerja, PT. Raja Grafindo Persada, Jakarta 